\title{
ВЕРОВАНИЯ И ОБРЯДЫ КАРАКАЛПАКОВ, СВЯЗАННЫЕ С РЫБОЛОВСТВОМ
}

\begin{abstract}
В данной научной статье освещается проблема изучения древних реликтов, верований, обрядов и культов каракалпаков, связанных с рыболовством. До недавнего времени многие из них бытовали в народной среде, а сегодня сохраняются в мифологии и фольклоре. Автор анализирует особенности почитания рыб в образах духов-покровителей, зооморфные черты в культе предков, а также исследует историко-культурные связи каракалпаков с другими народами для установления общцих закономерностей в истории религиозных верований, связанных с рыболовством.
\end{abstract}

Ключевые слова: Верования, культ плодородия, обряды, обычаи, традициии

Каракалпаки Южного Приаралья в силу исторических причин сохраняли до недавнего времени древние обычаи и верования, которые исчезли или деформировались у других народов. Среди доживших до наших дней верований - те, что связаны с ловлей рыбы. Рыболовство у каракалпаков является издавна является традиционным занятием. В Аральском море и в Амударье нет рыбы харам-недозволенной к употреблению в пищу. Вся рыба в Каракалпакии считается халал - чистой, то есть пригодной для приготовления пищи.

О большом значении рыболовства в жизни коренного населения свидетельствуют древние и средневековые письменные источники. По описаниям Геродота «...массагеты ничего не сеют, а живут за счет скотоводства и рыбной ловли, а также пьют молоко» (Геродот 1972: 216). По сведениям древних авторов, правители Средней и Центральной Азии, считая рыб священными животными, носили шлемы с изображениям золотой рыбы (Бичурин 1950: 276). Арабские географы, в частности, Ибн Русте писал о местности Холиджан, где ловится рыба, «которую вывозят в окрестные места». Ал-Истахри сообщал о низовьях Амударьи, что «Джайхун доходит до Хорезмского озера в месте, где живут рыбаки» (Волин С.Л. и др. 1938: 179).

Академик АН РУз Я.Г. Гулямов доказал, что местность Холиджан совпадает с современной территорией Муйнакского Рыболовецкого района (Гулямов 1957: 126). Основными аулами каракалпаков, жители которых занимались рыболовством еще

Есбергенова Светлана Хожакметовна - кандидат исторических наук, докторант Каракалпакского научно-исследовательского института гуманитарных наук Каракалпакского отделения Академии наук Республики Узбекистан (230100. Республика Каракалпакстан, г. Нукус, ул. Режиссеры, 13). Эл. почта: yesbergenova.svetlana@mail.ru. Esbergenova, Svetlana Hozhakmetovna - Karakalpak Research Institute for the Humanities of the Karakalpak branch of the Academy of Sciences of the Republic of Uzbekistan (Uzbekistan, Nukus, Rejisser St., 13). E-mail: yesbergenova.svetlana@mail.ru 
в первой половине XIX в., являлись - Тербенбес, Мерген - атау, Тазбескум, Акботкей, Тайлак - жеген, Карабайлы, Ержан-атау, Акала, Урге, Каражар, Айырша, Дузлы, Кайберен, Жумалак, ЖегеБозатау и др. Велась рыбная ловля и в таких озерах, как Коныраткол, Каратерен (Тахтакупырский район), Шегекол (Муйнакский район), Машанкол, Судочье, Айбуйир (Кунградский район),

У огузов в Х в. вода считалась одной из почитаемых стихий, и поэтому с ней был связан ряд запретов. Считалось недопустимым купание или омовение водой и стирка нательного белья. Омовение рассматривалось как колдовство. Непосредственно с водой были связаны верования в русалок или человекообразных рыб, обитавших в Аральском море. Существовало поверье о том, что своим появлением на водной поверхности и криком они предвещают о смерти огузских вождей (Агаджанов 1971: 182).

С древнейших времен каракалпаки унаследовали обычаи, предусматривающие сохранение водоемов в чистоте, бережное отношение к окружающему миру природы. По реликтам древних верований вода и рыболовецкий инвентарь: қайық (лодка), $a \check{y}$ (сеть) имели сакральные свойства. Например, чтобы забеременеть, бездетные женщины переезжали на лодке через Амударью и устраивали садака-жертвоприношение богу. С такой же целью бездетные женщины трижды обходили вокруг мачты лодки опытного рыбака и прикасались к ней. Покровителем лодки считался святой Hyx (библейский Ной).

Согласно известным предписаниям мусульманства в Каракалпакстане, дозволенными к пище считалось мясо тех животных, которые были баўызланzан, то есть горло которых было перерезано и из него выпущена кровь. Дичь убитая на охоте, которой не было перерезано горло, считалась несъедобной - харам. Однако эти правила не распространялись на рыб, так как они считались священными, райскими животными. У каракалпаков, узбеков (Снесарев 1969: 326), туркмен (Басилов 1963: 1-147) существует предание о том, как некий Намут Капир (иногда каракалпаки его называют Феридун), выстрелил в небо, чтобы убить бога. Но, пророк Муса, сделал так, что стрела попала в рыбу, которая затем была сброшена им на землю. От этой стрелы у рыбы появлялись жабры и таким образом, у рыбы богом перерезано горло и выпущена кровь. Мясо и кровь рыбы у каракалпаков считаются обладающими очистительными и лечебными свойствами. В этих легендах и верованиях особенно обращает наше внимание персонаж Феридун.

Т.А. Жданко отметила отношение населения к рыбам и птицам, сохраняющее следы тотемистических представлений предков каракалпаков. По их поверьям, в противоположной, враждебной человеку роли выступает сом, проглатывавший живых людей и приносивший вред местностям и городам (легенда о Куюк кале).

Один из видов сома $а қ$ ылақ̧ - запрещалось есть на белой кошме, в полосатой тени (т.е. в тенистом месте с проникающими сквозь решетку юрты световыми пятнами. Считалось, что несоблюдение этого правила вызывает заболевание проказой (Жданко 1961: 27-43). Довольно большое видовое разнообразие рыб в Амударье и внутренних озерах позволяло каракалпакам, жившим у воды, быть разборчивыми в выборе сорта рыбы. Наиболее ценными породами, употребляемыми в жареном виде являлись осетровые, называемые бекре. Осетровые считались деликатесом, жир их употребляли в лечебных целях. Совершенно непопулярна была у каракалпаков щука (иортан). 
Орудия рыболовства, в первую очередь лодки, имели связь с древними культами. Так, носовая часть амударьинского (каракалпакского) каюка оформлялась в форме человеческой головы. В центре традиционно помещалось зеркало. Поблизости от него прибивали кусок бархата, на который нашивались монеты и амулеты. Вдоль бортов каюка тянулись длинные косы, сплетенные из конского волоса. Нос лодки в форме головы - это поклонение Хозрати Нуху - пиру каючников. Через века до нас дошла информация о том времени, когда на каюке изображался торс женщины - покровительницы. И длинные косы, по поверью, вдоль бортов были ее косы. Так было до прихода ислама. С утверждением этой религии обычай претерпел изменения. У женской фигуры было срублено лицо, остались только две косы.

Важно отметить, что описанный облик каракалпакского каюка соответствовал оформлению каюков, распространенному у узбеков Хорезма (Снесарев 1968: 247-248).

Информация, записанная от даргашы (лодочника), который плавал на лодке 18 лет, позволяет описать внешний вид лодки (ПМА 2010, № 8). Большая лодка длиной 15-16 м, шириной 3-4 м называлась айдарль кеме (ушан кеме), то есть лодка с косой на макушке. На носовую часть лодки наносились орнаменты темно-коричневой охрой. С двух боков его свешивались косы, сплетенные из конского или бычьего волоса от хвоста и напоминающие женские косы. Покровителем лодочников считался первый пророк Нух. Другой информатор (ПМА 2010, № 10) сообщил о том, что с двух сторон носовой части лодки на борта, куда не доходила вода, наносили орнаменты красной охрой или вырезали ножом изображение рыбы.

Представления о сверхъестественных (сакральных) силах Амударьи имели большое распространение среди бесплодных женщин. Каракалпачки, узбечки, желая стать матерью, находили общий язык с лодочниками и рыбаками. Они переезжали на другой берег реки, бросая в ее воды жертвенные хлеб и соль, призывая при этом себе в помощь свою покровительницу Амбар - ану.

Большинство поверий и легенд в материалах Г.П. Снесарева, касающихся Амударьи, воссоздают сюжеты и образы героев древнеиранской эпической традиции. Не случайно основным из персонажей является Феридун (Трэтаона «Авесты»), образ которого тесно связан со стихией воды и восходит к тотемистической Фратрии быка (Толстов 1948: 292-303). С этим героем каракалпаки связывают и легенду о рыбе. По реликтам древних верований, рыболова надо оберегать от «сглаза». Поэтому распространенным было символическое обращение к отправлявшемуся на рыбную ловлю или встречаемому рыбаку с пожеланием успеха - қзазамайласын (қаза-загородка из камыша для ловли рыбы) - «пусть будет большой улов»!

Отправляясь на промысел, рыбак никогда не сообщал о предстоящей рыбалке, не говорил об улове, он избегал встречи с кем либо в дороге. Это объяснятся тем, что водяной (т.е. покровитель рыб) любит людей, которые умеют хранить тайны. В связи с этим возникла поговорка: «Балықшы айтар бир асым, Сирә айтпайды расын» (У рыбака улов всегда на одну уху, никогда не скажет правду!) (ПМА 2010, № 11).

У рыбака, который говорит о предстоящей рыбалке, якобы будет шәмшил - (сглаз) и она закончится неудачей. Промысловики не любили заранее принимать заказы на лов определенного вида или количества рыбы. И сейчас еще потомственные рыбаки в поселке Казакдарья, которых если по дороге на рыбную ловлю кто-либо попросит наловить рыбы определенного вида, тут же возвращаются домой, боясь неудачи. Рыбак не может ловить рыбу по своему выбору и желанию, поскольку верит, что рыбу 
ему дает покровитель. Кто хвастается или заранее дает обещание, говорили старики, тот может встретиться с хозяином рыбы и получить наказание. Нами выявлены реликты первобытного общественного труда и общественной раздачи продуктов $\mathrm{cbl}$ paлzы - раздача односельчанам рыбы из улова. Например, в поселке Порлытау, когда один рыбак привез свой улов на приемный пункт рыбзавода, к его лодке подошли несколько человек мужчин. Каждый взял что-то по своему выбору и унес домой, остальную рыбу рыбак сдал приемщику.

Продолжает бытовать обычай шонтай түби (дно невода), по которому любой встречный человек может взять рыбу, чтобы сварить уху для семьи. Рыбак не имеет права отказать, ибо обычай это не разрешает.

Однако категорически запрещалось давать рыбу из своего улова тем женщинам, которые находятся в месячных очищениях, в чилле (сорокодневка после родов) или в период жерик (токсикация у беременной женщины), а также для кавынымм (знахарский способ лечения больных рыбой). Это поверье, очевидно, сложилось на основе суеверного представления о «нечистоте» женщины в течение сорока дней после родов. Если женщины все же брали рыбу, нарушив запреты, в компенсацию за нарушение обычая они давали рыбаку (чтобы ему не повредить) хлеб, пшено, платки, деньги. Считалось, в это позволит ему добиться хорошего улова. В случае неудачного лова для рыбака, который закидывал невод, выполнялся магический обряд: снимали грузила с того невода, в котором был хороший улов, и привязывали их к неводу неудачника. Аналогичные обычаи, связанные с неудачным уловом и способами борьбы с ними, отмечены у туркмен (Демидов 1963: 44).

У промысловиков получили распространение исламизированные реликты доисламских верований, напоминающие запреты, связанные с охотой. Охотникам запрещалось убивать зверей в излишнем количестве. Что касается рыбаков, то рыбак должен был посеять столько зерен злаков, прежде всего ячменя, пшеницы, сколько рыб он отловил за свою жизнь, ибо рыба - живое существу и лишать жизни чрезмерно много рыбы считалось грехом. В 50-х годах XX столетия сильно возросли уловы благодаря усовершенствованию техники рыболовства. В связи с этим, боясь согрешить, часть ловцов рыболовецких колхозов поменяли профессию, подавшись в земледелие.

Интересно, что представления о компенсации грехов посевами злаков встречаются в текстах «Авесты»: «Тот, кто выращивает ячмень, - говорится в третьей песне Вендидада - выращивает праведность так же, как если бы он противостоял тысяче демонов, совершил тысячу жертвоприношений и вознес тысячу молитв» (Чурсин 1913: 44).

Возможно, поверья, связанные с запретом излишнего лова рыбы, возникли сначала с природоохранной целью, а затем приобрели характер табуации тотема. В обычае каракалпаков не выбрасывать костей рыбы в огонь, вероятно, прослеживается перевоплощение рыб в людей и обратно. Например, в народной сказке «Алтын сазан» («Золотой сазан»), в образе сазана выступает мужчина - лекарь, превращенный в рыбу (Баскаков 1951: 111-114). По мнению рыбаков побережья Аральского моря, у каждой рыболовецкой ватаги был свой хан, которого рыбаки выбирали с учетом его профессионального опыта и признавали за пира. Некоторые информаторы считали, что покровителем рыбаков являются Балыкши-ата и Мардан-ата.

Ханами становились удачливые рыбаки, которых называли қоль қ̧анльl (руки с кровью). Народ верил в то, что хан рыбаков мог разговаривать с рыбами (ПМА 1999, 
№ 8). Прежде чем отправиться на промысел ханы делали из коллективных средств - жоллық - жертвоприношение богу, то есть покровителям рыбаков, устраивали общественное угощение, раздачу съедобных вещей, выполняли обряд қ̧ан шашыў- обрызгивание кровью, для чего резали иногда крупный рогатый скот.

Особенно торжественно справляли бас таңъъы - ритуальный праздник в честь того, кто впервые участвует в рыбной ловле или по случаю первого выхода молодого рыбака на самостоятельный лов. Первый улов раздавался односельчанам во имя бога. Рыбу ловили с помощью каза (загородка из камыша для ловли) или жилым (невода). Ватага объединяла до 100-300 рыбаков.

Избранный ими хан назначал место и время начала рыбной ловли. В его распоряжении были рыбаки, рыболовные принадлежности, добыча. Аналогичный порядок существовал и у аральских узбеков. Рыбаки помнят хана рыбаков Мамута, который знал следы рыбы, то есть умел определять местонахождение рыбы под водой и или подо льдом. Информатор Оспанов Курбанияз рассказал о своем отце Оспане, который был предводителем (ханом) над 200-300 рыбаками. Однажды к нему явились более 500 рыбаков, чтобы узнать секрет отца, как определить месторасположения рыб подо льдом. И отец объяснил, что он осенью делает разведку, где водится много рыбы. Когда вода замерзнет, подо льдом рыбы не уплывают далеко от того места, где были осенью, поэтому он зимой проводил рыбаков в выбранный водоем и ему сопутствовала удача (ПМ 1970, № 19).

Представители старшего поколения до сих пор полагают, что болезнь вызывается злым духом, воплотившимся в тело человека, злым духом, которого нужно изгнать. Это - наивное объяснение причин болезни, унаследованное от эпохи первобытно-общинного строя, отличается от развитых религий более поздних эпох согласно которым судьба человека предопределена богом.

Со стремлением изгнать злого духа из тела больного связан обычай, предусматривающий удар по голому телу больного сазаном. Этот способ «лечения» считался особенно действенным при рези в животе - иле. Иногда применяли способ лечения қ̧анлайды - голое тело больного поливали свежей кровью рыбы. Использованный для знахарского лечения сазан употреблялся порханом или знахарем в пищу.

Некоторые больные, особенно бездетные женщины, применяли сазан булау - $а$ зан токли, а полученную массу укладывали в тряпку и привязывали к животу и держали несколько часов. Иногда вместо целой рыбы брали какую-либо ее часть, чаще всего жир. Осетровую икру рекомендовали тем, кто страдал воспалением легких и туберкулезом. Для избавления от простуды, особенно от кашля назначали желчь сазана. Мясо щуки и сома и рекомендовалось для лечения, так как они были хищными. Среди лечебных средств высоко котировался сазан. Лекари учитывали, что рыба эта питается растениями и она полнокровная. Сорок сазанов имеют кровь одного человека (то есть количество их крови равно крови человека). Кровь сазана быстро впитывается и смягчает тело человека. У кого болели зубы, во рту держали кровь сазана, через определенное время ее выплевывали. Больным туберкулезом предлагали пить кровь сазана. По сообщению информатора, его дед Карлыбай - табиб (лекарь), проживавший в конце XIX-начале XX в. на территории Муйнакского района, с помощью жира осетра и плавников сома избавлял больных от туберкулеза (ПМА 2001, № 7). Существовал запрет есть сома и запивать его кислым молоком. Считали, что человек может заболеть проказой. 
Известен обычай гадания с помощью рыбы, которым полагалось заниматься только пожилым женщинам. Когда рыба варится поднимая рот вверх, то сверху ухи брали жир и лили в рот рыбы, приговаривая: «Майла-майла» (Пусть будут богаты уловы у рыбака)!

О путниках, особенно о заблудившихся в море людях гадали по қырдыщи - жаберной кости рыбы. Бросали ее в костер и держали до появления трещин. Если трещина начиналась с края жабры и доходила до головы, то предполагали, что рыбак или путник благополучно вернется домой (рис. 1).

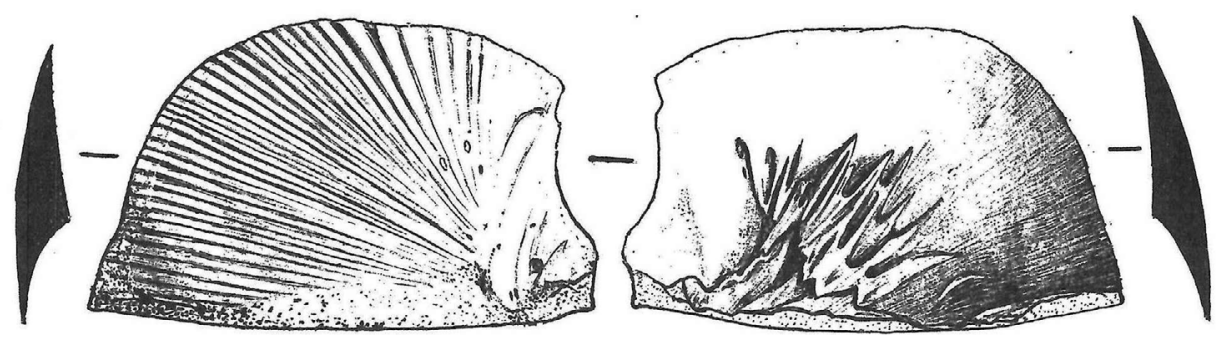

Рис. 1. Кыргыи -жабреная кость рыбы.

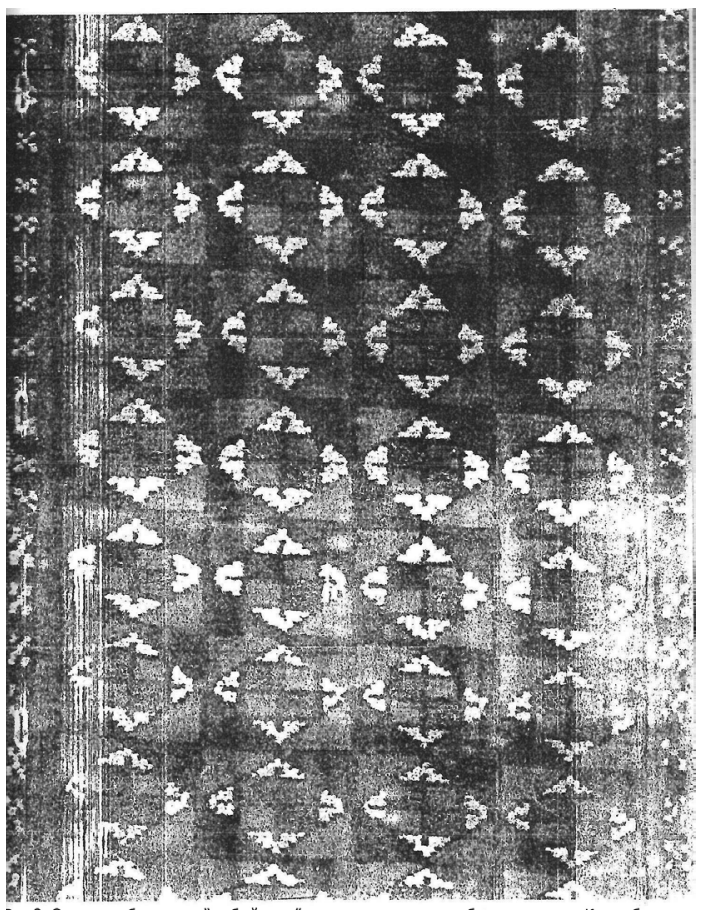

Рис. 2. Орнамент балык коз «рыбный глаз» в узорном ткачестве убранстве юрть Кызылбаскур.

Вероятно, у предков каракалпаков существовал культ рыбы. Еще в XIX -начале XX в. некоторые рыбы считались священными - ем (целебными). На мысль о былом существовании культа наводят водоемы со священными рыбами. Исключительной известностью пользовались огромные сазаны, обитавшие в пруду при мазаре Султан Вейс баба (VIII в. Берунийский район). Верующие, совершавшие паломничества к этому мазару, кормили священных рыб. С рыбами мазара связано множество легенд, сводящихся к тому, что если кто-либо посягнет их неприкосновенность, неизбежно будет наказан болезнью или даже смертью. В сравнительно недавнем прошлом ливень, вызвавший в долине наводнение, повредил «священный» пруд. Огромный камень упал в него, и одна из рыб была убита. Шейхи мазара завернули ее в саван и, совершив джиноза, похоронили как человека около могилы святого. Уподобление рыбы человеку в похоронном ритуале представляется весьма примечательным в плане живучести реликтов древних тотемистических 
представлений (Снесарев 1969: 326). Аналогичные водоемы со священными рыбами и связанной с ними мифологией имеются в местности Ак туба Кегейлийского района, Сафа кол (Улетевшее озеро) в Амударьинском районе.

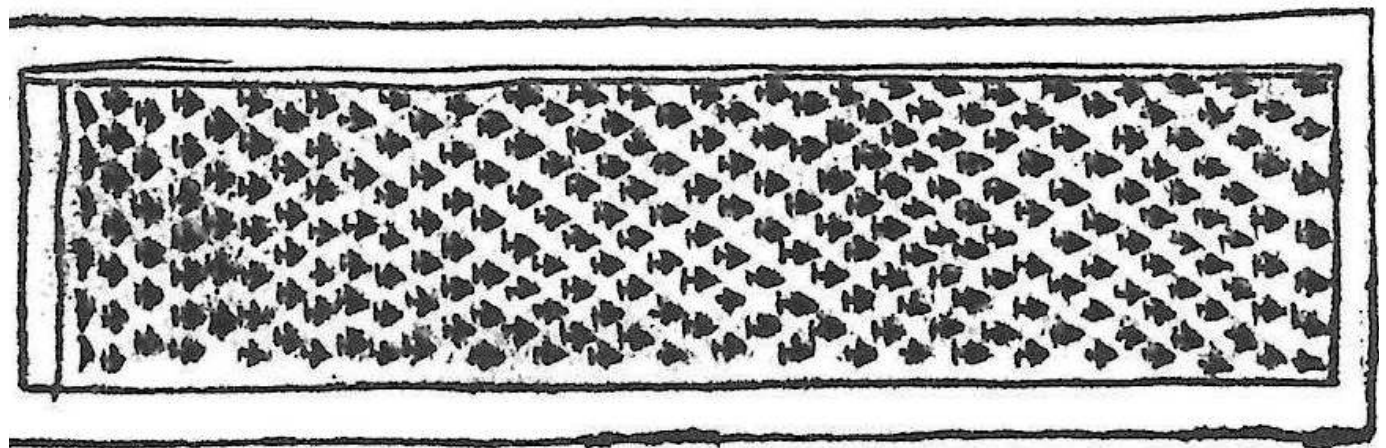

Рис. 3. Изображение рыб в узорном ткачестве есик кас над дверью юртыл.

О древности рыболовства у каракалпаков говорит изображение рыб в произведениях узорного ткачества. Орнамент балықкөз (рыбий глаз) присутствует в произведениях прикладного искусства. Традиционными являются қызылбаскур (алаша) (рис. 2) и есикқ̧ас (над дверью юрты) (рис. 3) (КГМ. Ф. 3, от. МПИ, кП. 4268, инв, № T-111).

Первоначальное изображение глаза рыбы, вероятно олицетворяло живую рыбу и служило магическим средством. «Убивая» или «раня» изображения, древние охотники верили, что подобным актом они обеспечивают удачу на промысле. В обычае каракалпаков не выбрасывать костей рыбы в огонь возможно прослеживаются реликты веры в реинкарнацию - способность тотема воплощаться в группу людей и обратно. Аналогичные верования и обряды, связанные с водной стихией бытовали у узбеков, туркмен, киргизов и других народов (Басилов 1963; Демидов 1963; Снесарев 1969; Абрамзон 1971; Борозна 1975; Баялиева 1972; Алексеев 1980). Верования, связанные с рыболовством, чаще всего прослеживаются среди каракалпаков арысов «қ̧оџырат», чем «он төрт уру». Это объясняется тем, что для последних было характерно, в основном земледелие и животноводство. В верованиях и обрядах каракалпаков связанных с рыболовством прослеживаются реликты тотемизма, магии промыслового культа. Почитание рыб являлось широко распространенным явлением у каракалпаков, туркмен, чем у оседлых узбеков, занимавшихся в основном земледелием.

Археологические исследования свидетельствуют о том, что истоки моления, жертвоприношения Амударье и в промысловом рыболовстве со стороны предков каракалпаков и других народов Южного Приаралья связаны с культом хозяина рыболовства. Об этом говорят изображения парусного судна с двумя схематическими человеческими фигурами на нем (Рис 4), наскальные знаки, рисующие хозяйственную деятельность человека, и знаки протохорезмийской письменности, обнаруженные на скалах Кара тюбе, Беш тюбе близ Чилпыка (Амударьинский район). С.П. Толстов датировал наскальные начертания времен от III до начала I тысячелетия. Анализ названных исторических памятников заставляет задуматься относительно истоков культа и реликтов магии, связанной с хозяйственно-производственным бытом народа (Толстов 1948: 71-76). 
Раскопки археологических памятников в дельте Амударьи позволили выявить костяные изделия VII-VIII вв. с изображением рыбы (Гудкова 1964: 57, рис. 4). При проведении археологических раскопок в 1998 г. в средневековом городе Кердер, расположенном на правом берегу Амударьи археологом М. Мамбетуллаевым был обнаружен фрагмент чаши, во внутренней части которой были изображены фигуры птицы (орла), в когтях держащей змею. Параллельно вдоль крыла птицы изображена фигура рыбы. Находка датируется IX-X вв. Пара рыб со змеей может означать супружескую чету, так как рыба - символ плодовитости.

Культ рыб распространялся по всей Центральной Азии, захватывал Закавказье и Кавказ, своими корнями был аналогичен верованиям древнего населения Перед-

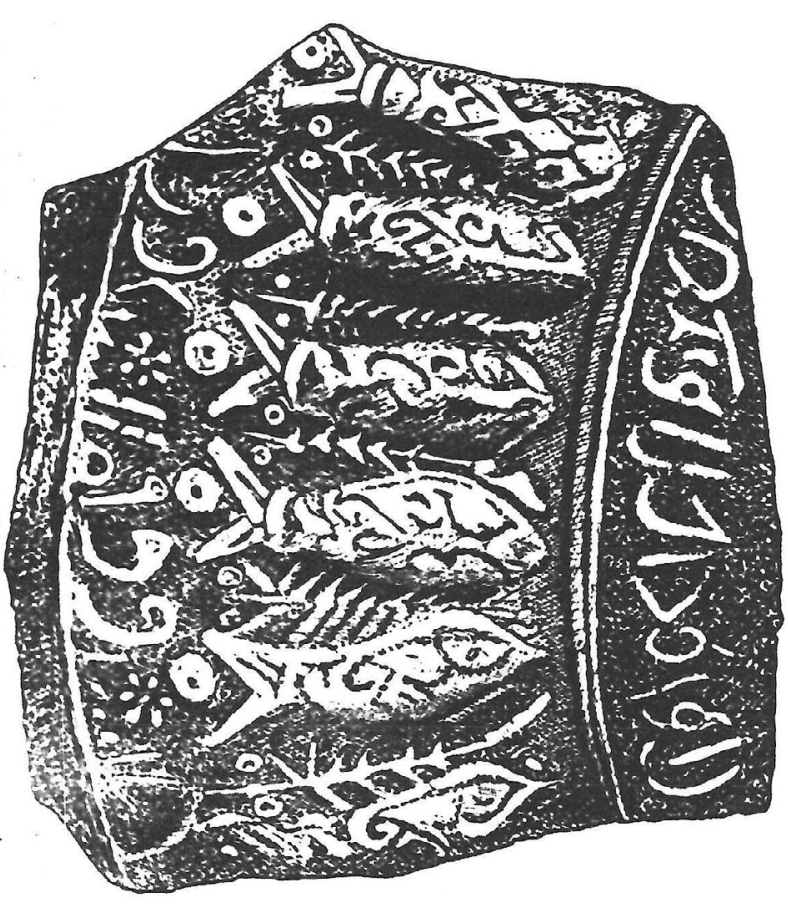

Рис. 4. Изображение рыб на керамике XII-XIII вв. с территории Южного Туркменистана. ней Азии Средиземноморья. Пережитки этого культа имели место в зороастризме, который, видимо, способствовал тому, что культ рыбы еще долго существовал, сохраняясь в виде реликтов, даже в мусульманское время. Излюбленный сюжет в искусстве Древнего Востока, истоки которого уходят в пласты космогонических представлений, мотив борьбы и победы сильного над слабым, частично символизировавший идею царского могущества, довольно реалистично запечатлен на Кердерской посуде. Связь этого мотива с древними космогоническими, мифическими и эпическими представлениями становится очевидной при сравнении памятников этой эпохи с образцами доисламско-

го времени с изображением птиц и рыб.

Столкновение различных стихий, воплотившихся в образах животных, птиц, змей, рыб и т.д. было распространенным мотивом древнего искусства на стадии анимистических и космогонических представлений. Нам представляется, что изображение птиц, змей и рыб на Кердерской керамике символизировало борьбу воздушной и водой стихий. Таким образом, древний сюжет, имевший различные стадии смыслового развития и интерпретации в IX-XI вв., обрел значение сказочного сюжета, выраженного на изделиях этого времени соответствующим изобразительным фольклором в декоративных орнаментальных формах. 
С другой стороны, представленные на сосуде птица-рыбы-змея можно интерпретировать с точки зрения мифологии. Их можно рассматривать в плане вертикальной структуры мира, представленной мировым деревом (верх-крона-птицы, серединаствол--копытные или рыбы; низ-корни- животные или змея). Здесь основообразующим персонажем в модели мира становится змея (Мамбетуллаев 1999: 290, 386).

При раскопках Куюккалы и Курганчи в слоях VII-VIII вв. обнаружены жаберные кости, предназначенные для гадания (Мамбетуллаев, Утемисов 1973: 61). На раскопках Якке-Парса средневекового городища найдены изображения рыб. Изучение находок позволило сделать вывод о том, что люди того времени воспринимали рыб с позиции священных животных (сакральных) (Мамбетуллаев 1978: 85). Кости рыб были найдены на всех стоянках Джанбасского такыра, в могильнике Тумек-Кичиджик (Виноградов 1981: 142).

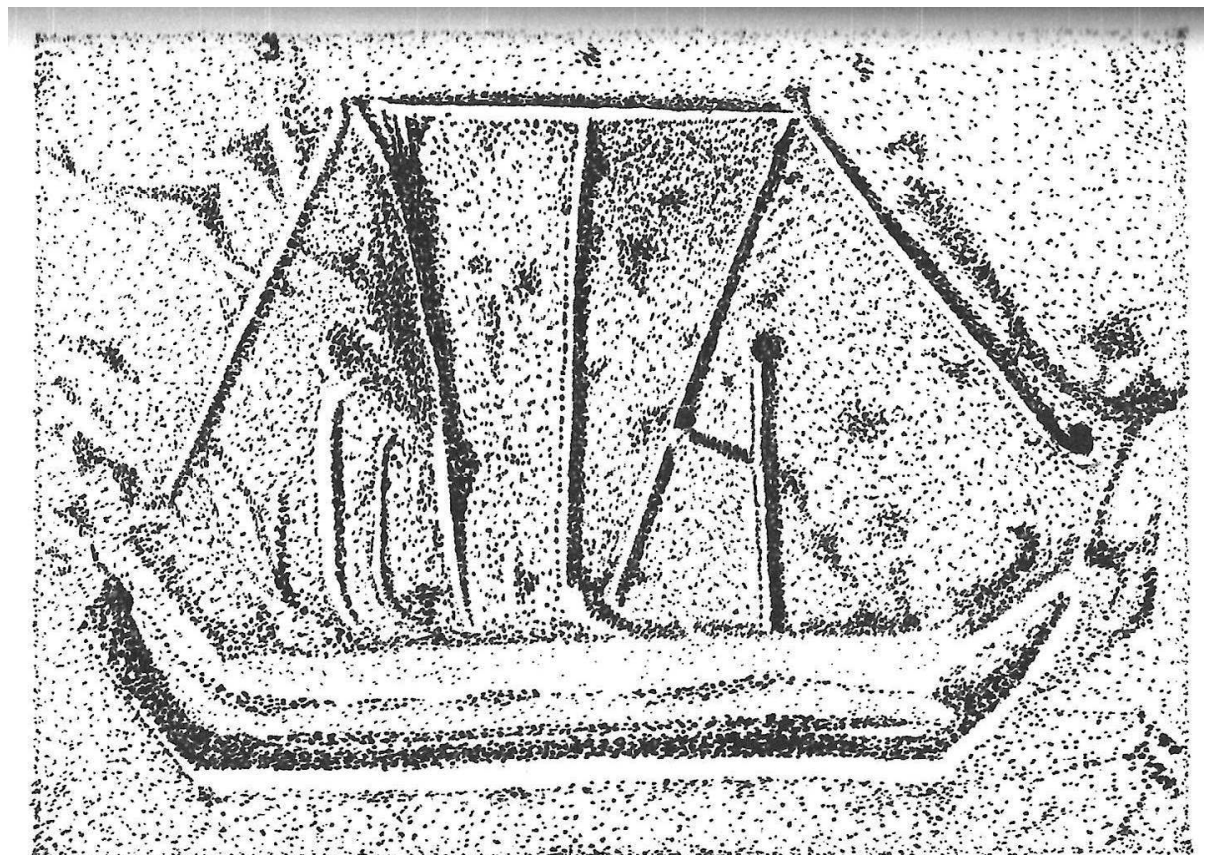

Рис. 5. Изображение парусного судна с двумя схематическими фигурами на нем оз. Беш тюбе (время от III начала I тысячелетия).

Сюжеты с изображениями рыб обнаружены на керамике со штампованной орнаментацией из гончарной мастерской XII-XIII вв. в квартале керамистов Старого Мерва (рис. 5) (Лунина 1960: 81-109).

Изучение вопросов о верованиях и обрядах каракалпаков, связанных с рыболовством, проявляющихся в мифологии, верованиях, произведениях фольклора, среди орнаментов одежды, жилищ, ювелирных предметов и др., является важным источником в изучении истории и истории культуры каракалпаков, без учета которых невозможно воссоздать цельную историю и в полном объеме раскрыть самобытность каракалпакского народа, выявить истоки его стремления к духовно-нравственному возрождению в условиях независимости, а также разработать сложную проблему этнокультурных связей. 


\section{Источники и материалы}

ПМА 2000, № 8 - Полевые материалы автора № 8.Экспедиция в Муйнакский район, село Шеге, 2000 г. (Информант - Аймуратов Курбанбай, 1924 г.р.).

ПМА 2000, № 10 - Полевые материалы автора № 10. Экспедиция в Муйнакский район, село Шеге, 2000 г. (информант -Ембергенов Жумамурат, 1933 г.р.).

ПМА 2000, № 11 - Полевые материалы автора № 11.Экспедиция в Муйнакский район, село Тентек,2000 г. (Информант - Каипов Кайырбай, 1936 г.р.).

ПМА 1999 № 8 - Полевые материалы автора № 8.Экспедиция в Муйнакский район, село Шагырлы, 1999 г. (Информант - Ешмуратов Кутлымурат, 1915 г.р.).

ПМА 1970, № 19 - Полевые материалы Х. Есбергенова № 19.Экспедиция в Чимбайский район, поселок Шахаман, 1970 г. (Информант - Оспанов Курбанияз, 1898 г.р.).

ПМА 2001, № 7 - Полевые материалы автора № 7. Экспедиция в Муйнакский район, село Шеге, 2001 г. (Информант - Низаматдинов Наурызбай, 1930 г.р.).

КГМ - Каракалпакский Гос. Музей им. И.В.Савицкого. Фонд 3, отдел МПИ, кп. 4268, инв, № T-111.

\section{Научная литература}

Абрамзон С.М. Киргизы и их этнографические и историко-культурные связи. Ленинград: Наука, 1971. $307 \mathrm{c.}$

Агаджанов С.Г. Огузские племена Средней Азии IX-XIII вв. Историко-этнографический очерк. - СБ. «Страны и народы Востока». Вып. Х. М.: Наука, 1971. 182 с.

Алексеев Н.А. Ранние формы религии тюркоязычных народов Сибири. Новосибирск: Наука, 1980. $115 \mathrm{c}$.

Басилов В.М. О пережитках тотемизма у туркмен // Труды ИИАЭ АН Туркмен ССР. Т. 7. Серия этнографическая. Ашхабад: АН Туркмен ССР, 1963. 147 с.

Баскаков Н.А. Каракалпакский язык // Материалы по диалектологии. Т. І. Москва: АН СССР, 1951. C. 111-114.

Баялиева Т.Д. Доисламские верования и их пережитки у киргизов. Фрунзе: Илим, 1972. 285 с.

Бичурин Н.Я. Собрание сведений о народах, обитавших в Средней Азии в древние времена. Т. I. М.; Л.: АН ССР, 1950. 276 c.

Борозна Н.Г. Некоторые материалы об амулетах-украшениях населения Средней Азии. Сб.: Домусульманские верования и обряды в Средней Азии. М.: Наука, 1975. 285 с.

Виноградов А.В. Древние охотники и рыболовы Среднеазиатского Междуречья. М.: Наука, 1981. $142 \mathrm{c}$.

Геродот. История в девяти книгах. Л.: Наука, 1972. Кн. 1. 216 с.

Гудкова А.В. Ток-кала. Ташкент: Фан, 1964. 57 с.

Гулямов Я.Г. История орошения Хорезма (С древнейших времен до наших дней). Ташкент, 1957. $126 \mathrm{c}$.

Демидов С. О пережитках верований, связанных с водной стихией и рыболовством у туркмен // Труды Института истории, археологии и этнографии. T.VII. Серия этнографическая. Ашхабад, 1963. № 7. С. 44.

Жданко Т.А. Работа каракалпакского этнографического отряда в 1956 г. Материалы Хорезмской экспедиции. Вып. 1. М.: Наука, 1959. 207 с.

Жданко Т.А.Быт колхозных артелей на островах Южного Арала // Советская этнография, 1961. № 5. C. 27-43.

Лунина С.В. Зооморфные сюжеты в керамике со штампованной орнаментацией из гончарной мастерской XII - нач. XIII вв. Квартал керамистов Старого Мерва // Труды ТашГУ. Вып. 172. T. V. Ташкент, 1960. С. 81-109.

Мамбетуллаев $M$, Утемисов А. Некоторые пережитки верований у каракалпаков, связанные с рыболовством // Вестник ККФАН УзССР, 1973. № 4. С. 61. 
Мамбетуллаев М. Городище Большая Айбуйир-кала (Раскопки 1976 г.) // Вестник ККФАН УзССР, 1978. № 4. С. 85.

Мамбетуллаев М. Кердерская чаша // История материальной культуры Узбекистана, 1999. № 30. С. 386-290.

Волин С.Л. и др. (под ред.) Материалы по истории туркмен и Туркмении (МИТТ). Т. І. М.; Л.: АН СCCР, 1938. $179 \mathrm{c}$.

Снесарев Г.П. Реликты домусульманских верований и обрядов у узбеков Хорезма. М.: Наука, 1969. $326 \mathrm{c}$.

Толстов С.П. Древний Хорезм. М.: МГУ, 1948.

Чурсин Г.Ф. Очерки по этнологии Кавказа. Тбилиси, 1913.

\section{References}

Abramzon, S.M. 1971. Kirgizy i ih jetnograficheskie i istoriko-kul'turnye svjazi [Kirgiz and Their Ethnographic, Historical and Cultural Relations]. Leningrad: Nauka.

Agadzhanov, S.G. 1971. Oguzskie plemena Srednej Azii IX-XIII vv. Istoriko-jetnograficheskij ocherk. [The Oguz Tribes in Central Asia IX-XIII st. Historical and Ethnographic Essay]. In «Strany i narody Vostoka» X.

Alekseev, N.A. 1980. Rannie formy religii tjurkojazychnyh narodov Sibiri [Early Forms of Religion of the Turkic-Speaking peoples of Siberia]. Novosibirsk: Nauka.

Bajalieva, T.D. 1972. Doislamskie verovanija $i$ ih perezhitki u kirgizov [Pre-Islamic Beliefs and Remnants among the Kirgiz]. Frunze: Ilim.

Basilov V.M. 1963.O perezhitkah totemizma u Turkmen [About the Remnants of totemism among the Turkmens]. In Trudy Instituta istorii, arheologii i jetnografii Turkmen SSR. T. 7. Serija jetnograficheskaja [Transactions of IIAE AN Turkmen SSR. Vol. 7. A series of ethnographic]. Ashhabad: AN Turkmen SSR.

Baskakov N.A. 1951. Karakalpakskij jazyk [Karakalpak Language]. In Materialy po dialektologii. Vol. 1 [Materials on dialectology. Vol. 1], 111-114. Moscow: AN USSR.

Bichurin, N.Ja. 1950. Sobranie svedenij o narodah, obitavshih v Srednej Azii v drevnie vremena [Collection of Information about the Peoples Who Lived in Central Asia in Ancient Times]. Vol. I. Moscow; Leningrad: AN SSR.

Borozna, N.G. Nekotorye materialy ob amuletah-ukrashenijah naselenija Srednej Azii [Some Materials about Amulet Decoration of the Population in Central Asia]. In Sbornik: Domusul'manskie verovanija i obrjady v Srednej Azii [Collection: Pre-Islamic Beliefs and Rites in Central Asia], edited by G.P. Snesarev, V.N. Basilov. Moscow: Nauka, 1975. 285 s.

Chursin, G.F. 1913. Ocherki po jetnologii Kavkaza [Essays on the Ethnology of the Caucasus]. Tbilisi.

Demidov S. 1963. O perezhitkah verovanij, svjazannyh s vodnoj stihiej i rybolovstvom u Turkmen [About the Remnants of Beliefs Associated with the Water Elements among Turkmen]. In Trudy Instituta istorii, arheologii i jetnografii. Vol. VII. Serija jetnograficheskaja [Transactions of the Institute of History, Archeology and Ethnography. Vol. VII. Ethnographic Series]. Ashhabad.

Gerodot. 1972. Istorija v devjati knigah [History in 9 books], vol. 1. Leningrad: Nauka.

Gudkova, A.V. 1964. Tok-kala [Tok-kala]. Vol. 13. Tashkent: Fan.

Guljamov, Ja.G. 1957. Istorija oroshenija Horezma (S drevnejshih vremen do nashih dnej) [History of Horezm Irigation (From Anshient to Our Days)]. Tashkent.

Lunina S.V. 1960. Zoomorfnye sjuzhety $v$ keramike so shtampovannoj ornamentaciej iz goncharnoj masterskoj XII - nachalo XIII vv. Kvartal keramistov Starogo Merva [Zoomorphic Subjects in Ceramics With Stamped Ornamentation in a Pottery Workshop in XII-beginning XIII sent. Quarter of Ceramists of Old Merv]. In Trudy TashGU 172 (V): 81-109.

Mambetullaev, M. 1978. Gorodishhe Bol'shaja Ajbujir-kala (Raskopki 1976 g.) [Hillfort Big Ajbujir-kala (Excavation of 1976 year)]. Vestnik KKFAN UzSSR 4: 85. 
Mambetullaev, M. 1999. Kerderskaja chasha [The Kerder Bowl]. Istorija material'noj kul'tury Uzbekistana 30: 386-290.

Mambetullaev, M., and A. Utemisov. 1973. Nekotorye perezhitki verovanij u karakalpakov, svjazannye s rybolovstvom [Some Remnants of Karakalpak Beliefs Related to Fishing]. Vestnik KKFAN UzSSR 4: 61.

Snesarev, G.P. 1969. Relikty domusul'manskih verovanij i obrjadov u uzbekov Horezma. [Relics of Pre-Muslim Beliefs and Rituals of Horezm Uzbeks] Moscow: Nauka.

Tolstov S.P. Drevnij Horezm [Ancient Horezm]. Moscow: MGU, 1948.

Vinogradov, A.V. 1981. Drevnie ohotniki i rybolovy Sredneaziatskogo Mezhdurech'ja [Ancient Hunters and Fishermen of Central Asia Entre Rios]. Moscow: Nauka.

Volin, S.L. et al. 1938. Materialy po istorii turkmen i Turkmenii (MITT) [Materials on the History of Turkmens and Turkmenistan]. T.I. Moscow; Leningrad: AN USSR.

Zhdanko T.A. 1961. Byt kolhoznyh artelej na ostrovah Juzhnogo Arala [Life of Collective Farms Artels in the Islands of South Aral]. Sovetskaja jetnografija 5: 27-43.

Zhdanko T.A. 1959. Rabota karakalpakskogo jetnograficheskogo otrjada v 1956 g. Materialy Horezmskoj jekspedicii [The Work of Karakalpak Ethnographic Grpoup in 1956]. Vol. 1. Moscow: Nauka.

\section{Esbergenova, Svetlana $H$.}

\section{Fishing-related beliefs and rites of the Karakalpaks}

The article highlights the problem of studying ancient relics, beliefs, rites and cults of the Karakalpaks related to fishing Until recently these were still common among the people, but now are only preserved in mythology and folklore. The author analyzes forms of veneration of fish as guardian spirits and zoomorphic attitudes in the cult of ancestors. The historical and cultural ties of Karakalpaks with other peoples are explored to establish common patterns in the history of religious beliefs associated with fishing in Karakalpaks.

Key words: Beliefs, fertility cult, rites, customs, traditions 